\title{
Debt Repayment: A Typology
}

John J. Watson, St. Bonaventure University, USA

\begin{abstract}
This research paper presents a four-category typology of the debt market based on attitudinal and behavioral data associated with the repayment of student loans. Qualitative interviews incorporating the Zaltman Metaphor Elicitation Technique (ZMET®) as well as a quantitative survey were used to obtain the data so the typology could be created. The four groups identified were the Life Indebted, the Traditionalist, the Entrepreneur, and the Expedient Payee.
\end{abstract}

Keywords: Debt, Typology, ZMET, Credit, Consumer Debt.

\section{INTRODUCTION}

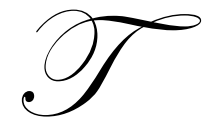

he recent collapse of financial markets internationally has put a spotlight on consumer debt. Debt is now a global issue and many countries, such as the U.S., New Zealand, and Canada, recognize that consumer debt is a growing concern. In the U.S., a college graduate carries $\$ 29,000$ in student loans and an average credit card balance of $\$ 2,327$ (Williams, 2004). In New Zealand, student debt is in excess of $\$ 7$ billion, and it has been estimated that ten percent of borrowers may not have the ability to repay their debt by the age of 65 (Student Loan Scheme Annual Report, 2002). In Canada, a study that examined the extent of indebtedness, repayment patterns, and effects of high debt on postsecondary graduates found that many graduates experienced difficulties in paying back loans because their earnings failed to keep pace with their loan payments (Clark, 1998). Because of these circumstances and the escalating costs of education, college students and recent graduates are an excellent segment to examine when studying consumer debt (O'Loughlin \& Szmigin, 2006). How are they handling their loans? What impact is it having on their financial future? This study aims to answer such questions by developing a typology based on both attitudinal and behavioral data associated with the repayment of student loans.

\section{LITERATURE REVIEW}

Contemporary society has been described as featuring a "culture of indebtedness" (Chien \& DeVanny, 2001). Current generations have grown up with easy access to credit, and as a result, people have become more tolerant and accepting of debt (Park 1993). Many people feel that if everyone is using debt, it must be okay (Parker 1988).

There are a variety of reasons why people go into debt. Researchers have identified a number of social, economic, and psychological variables that have explanatory power when matters of debt are examined (cf., Lea, Webley \& Levine, 1993; Lea, Webley, and Walker, 1995; Livingstone \& Lunt, 1992; Watson, 2003). Duesenberry (1949) suggests that social comparison may cause some people to borrow money in order to acquire products owned by members of their reference group. This "keeping up with the Joneses" mentality, coupled with the widespread availability of credit, and the relaxed attitudes toward debt has created an environment where many consumers feel that it is impossible to "survive" without going into debt (Lea, Webley \& Levine, 1993).

The change in attitudes toward debt has coincided with a commensurate rise in actual debt levels. Revolving credit card debt is close to $\$ 900$ billion and has increased an average annual rate of nearly nine percent over the past ten years (Scott, 2007). Household debt relative to disposable income increased from 60\% in 1980 to $104 \%$ at the end of 2003 (Christen \& Morgan, 2005). 
Once people are in debt, they may understand the problem which exists but tend to get further into debt as they have become accustomed to this lifestyle and way of living. For students who often come from relatively prosperous socioeconomic backgrounds, but have low income while studying, they perceive the situation to be temporary and are willing to incur some level of debt to sustain their usual lifestyle (Chien \& DeVaney, 2001; Modligliani, 1986).

The rapid rise in consumer debt and its repercussions for both the individual and society has been cause for concern. Hirschman (1991) called for consumer researchers to address this "darker side" of consumer behavior. Lunt and Livingstone (1991) suggested that debt is part of a more general concern about the rise of consumerism and the changing moral climate of borrowing and spending. We know that attitudes have shifted, that debt is common, but we know very little about the psychology of debt repayment or on the barriers of getting out of debt or helping consumers change their behavior (Thums, Newmaen \& Xiao, 2008). For this reason, we will examine attitudinal and behavioral data associated with the repayment of student loans with the aim of creating a typology of the debt market.

\section{METHODOLOGY}

\section{Qualitative Component}

Thirteen qualitative interviews based around the Zaltman Metaphor Elicitation Technique (ZMET®) were used for this study (Zaltman \& Coulter, 1995). ZMET® is a patented research technique, which involves a one-onone interview with participants. ZMET® is based on the premise that most human communication is non-verbal (Birdwhistell, 1970; Knapp, 1980; Seiter, 1988; Weiser, 1988), and a ZMET® interview revolves around a set of pictures that the participant brings to the interview. These pictures reflect the thoughts and feelings the individual has about the subject matter.

For this study, participants were instructed to gather "five to eight pictures that represent your thoughts and feelings about student debt." These pictures could come from any source, including photographs, magazines, books, newspapers, and catalogues, and the instructions were given five to ten days prior to the interview. Participants were contacted one or two days before their interview to confirm their understanding of the task.

Eight male and five female participants were interviewed, and the ages of the participants ranged from 22 to 29. All were college graduates. The interviews were conducted in a private room at a university and were recorded on both audiotape and videotape. Each interview took approximately one hour to complete. Data collection was concluded after 13 interviews because additional information was not being obtained.

\section{Quantitative Component}

Following the ZMET® interview, a quantitative questionnaire, which took another 5-10 minutes to fill out, was given to the participants. The questionnaire consisted of four sections: financial situation (e.g., current employment situation, income, assets, debt at graduation, current debt), attitudes towards debt (14-item scale by Davies \& Lea, 1995), expenditures (e.g., accommodation, travel, clothing entertainment), and demographic information (gender, age, marital status, etc.).

\section{Data Analysis}

The typology was created by comparing and contrasting responses and by grouping participants together based on their dominant motivations. It was an iterative process, and the typology evolved as the series of interviews progressed. All interviews were transcribed.

\section{RESULTS / TYPOLOGY}

Ultimately, five key factors were used to determine the typology categories. The five factors were: (1) how quickly the student loan was paid off, (2) whether more than the minimum payments were being made on the 
student loan, (3) credit card usage, (4) willingness to make financial sacrifices in the short-term to pay off the loan, and (5) attitudes toward debt.

Four distinct groups were identified: Life Indebted, Traditionalists, Entrepreneurs, and Expedient Payees. The key characteristics of each group are found in Table 1, and each group is described in detail in the following section.

Table 1: Key Characteristics

\begin{tabular}{|l|c|c|c|c|}
\hline & Expedient Payees & Entrepreneur & Traditionalist & Life Indebted \\
\hline Loans paid < 4 yrs. & Yes & No & No & No \\
\hline Minimum payments & No & Depends & No & Yes \\
\hline Credit card usage & Savvy & Savvy & Normal & Normal \\
\hline Sacrifice (expenditure) & Yes & Some & Some & No \\
\hline Attitudes Toward Debt & Low & High & Medium & Medium \\
\hline
\end{tabular}

\section{The "Life Indebted"}

The 'Life Indebted' pay the minimum amount possible off their student debt (10\% of their total earnings). These people treat these minimum repayments as an additional income tax and have resigned themselves to paying the 'extra tax' throughout their working lives-usually over a 20 - 40 year period. In some cases, the 10\% minimum repayment does not cover the accruing interest, and as a result, the Life Indebted may find themselves with an increasing student loan even though they are making their weekly compulsory repayments.

Although the Life Indebted acknowledge that having debt is not pleasant, they see the situation as being too difficult to solve. They like to have nice things, but there is a definite gap between the luxury goods they want and what they are able to afford. The Life Indebted have a favorable attitude towards debt, using overdraft and credit facilities to maintain a comfortable quality of life.

\section{Life Indebted: Profile Of The Participants}

Haley: 23 years old, Bachelor of Arts (Psychology), full-time Banking Consultant, one year in the workforce. Haley currently pays back the minimum 10\% of her total earnings on her student loan. She believes that it will take around 20 years to pay off her $\$ 39,000$ student loan.

Jessica: did not provide her age, Bachelor of Arts (Psychology and Political Science), full-time Banking Consultant. Jessica currently pays the minimum 10\% of total earnings on her student loan. Her student loan has increased from $\$ 48,000$ to $\$ 56,000$, and she believes it will take her 40 years to pay off.

Tony: 27 years old, Bachelor of Commerce (Marketing), full-time Assistant Manager, in the workforce for 5 years. Over 4.5 years Tony only paid the minimum 10\% of total earnings off his student loan; his \$40,000 Student Loan has not decreased.

The Life Indebted acknowledged that having student loans is not pleasant. Student debt brings on additional stress, as they acknowledge that this debt is something that they are always thinking about.

It is the additional stress that it can bring on. It is something that you are always thinking about in the back of your mind. It is frustrating; the frustration is knowing how much money you are wasting and the frustration of how to plan to pay it back-Haley (Life Indebted).

afford.

The Life Indebted like 'nice things', but there is a definite gap between what they want and what they can 
It is inhibiting me from doing the things I want to do. I would like to spend money on a house and living comfortable, going shopping, and doing things like that-Haley (Life Indebted).

They dream of escaping from their loans-either through bankruptcy or leaving the country. The Life Indebted want financial freedom, a life which is free from the pressure and restrictions their debt.

A $\$ 35,000$ loan sucks. If I 'jump ship' I can't come back because I would get caught for tax evasion plus my loan would get massive . . I can either pay it off or 'jump ship'. Both of my options are bad, I feel trapped-Ben (Life Indebted).

One Life Indebted participant, Tony, said that he has changed his repayment plan and will now pay off this student loan. Tony admitted that he did not previously care about the loan. Before Tony "woke up" he believed that he would have his student loan with him for the rest of his working life.

It is like having to wear glasses for the first time. I can actually see that the money that I owe to the government is actually real, and how much extra it would have cost me if I was just making minimum repayments-Tony (Life Indebted).

Now that he accepts that he has to pay off the loan, Tony has made the commitment to do so as quickly as he can. His current attitude is more consistent with our next group, Traditionalists.

\section{The "Traditionalist"}

Traditionalists are currently paying off their student loans. They feel positively towards student debt as they know that they graduated with a good degree and will succeed in the workforce. Traditionalists are financially responsible and know exactly what is happening with their loan repayments even though they feel that the system is difficult at times. To achieve their goal of financial independence Traditionalists tend to increase the minimum loan payments to service their student loan over a shorter period of time.

Traditionalists tend to live within their means, usually opting to live on a tight budget. They are not likely to take on further debt.

\section{Traditionalists: Profile Of The Participants}

Alistair: 25 years old, Bachelor of Science (Biochemistry), part-time accountant, 4 years in the workforce. Over the past 4 years Alistair has reduced his student loan from $\$ 16,000$ to $\$ 5,000$. He plans to have his loan repaid in full within the next 12 months.

Jordan: 25 years old, Bachelor of Medicine and Bachelor of Surgery, full-time doctor, in the workforce for 2 years. Over 2 years Jordan has downsized his student loan from \$82,000 to \$50,000. He plans to have his loan repaid in full within the following 4 years.

Helen: 23 years old, Bachelor of Arts (Geography and Sociology), full-time Assistant Manager, in the workforce for nine months. In nine months she has downsized her student loan from $\$ 16,000$ to $\$ 11,000$. She plans to have her loan paid off within the next 4 years.

Sasha: 22 years old, Bachelor of Commerce (Management), full-time Marketing Rep, in the workforce for 9 months. Sasha has decreased her loan from \$23,000 to \$22,500, but she recently increased her weekly repayments. She plans to have her loan repaid in five years.

Traditionalists acknowledge the positive side to their student debt. They know they graduated with a good degree and will succeed in the workforce. 
Going to college has given me so many opportunities. Without my student loan, I would not have been able to go to college, and without going to college, I would not be in the professional job where I am at the moment—Kevin (Traditionalist).

Even though the loan was like adding carriages to a train, whereby it was getting bigger and bigger by the year, having my degree has set me up for further things I want to do in life-Alistair (Traditionalist).

Traditionalists do not like the burden of having a loan and want to pay off the debt to get away from this unpleasant feeling of owing money.

You are attached to it. It stops you from doing things ... It is a burden. It is preventing me from making choices, because I have to pay back my student loan. And for me if I don't then I will be in debt and I don't want to be a person who is in debt as it affects if you can buy a house, your credit rating and possibly other things that may impede your future if it is not paid back-Sasha (Traditionalist).

Traditionalists intend to pay off their student loan and try to increase their minimum payments to service it over a shorter time period. They will frequently reduce expenses wherever they can.

I still live like I am a budget student in a cheap apartment so I can pay my loan off quicker-Kevin (Traditionalist).

Traditionalists feel that they will achieve financial independence once their loan has been paid off. This is symbolized by "being on top of the mountain of debt", "Climbing over the wall debt" or "filling in the hole that you have dug yourself by taking out the debt".

You are digging a hole, this is a financial hole which has to be filled in, and once it is filled in, you can continue as you have a good financial foundation as you are qualified and financially independent from your student debt-Alistair (Traditionalist).

The mountain is an object which is big, it is looming in front of you. As soon as you have got to the top, you have paid it off-Jordan (Traditionalist).

\section{The "Entrepreneur"}

Entrepreneurs still have student loans but have the resources to pay off the current balance. They choose not to pay off the loan because the return on that money is greater than the interest accruing on the loan. Entrepreneurs are very savvy when it comes to using money and knowing how to get money to work for them. They tend to use their credit cards as a payment tool but minimize bank fees and rarely have credit card interest payments. Their attitudes toward debt are favorable.

\section{Entrepreneurs: Profile Of The Participants}

Mike: 24 years old, Bachelor of Mechanical Engineering, two years in the workforce. Mike is currently a graduate student working towards a Masters in Engineering. In his first year in the workforce, Mike saved \$7,000 and then invested this money in a rental property. Mike has since sold the property and made a profit, which is over twice the amount he owes on his student loan.

Tim: 23 years old, Masters of Science (Chemistry), completing his training to be a teacher. While at school, Tim took out the maximum possible student loan and put the money on term deposit where it earned thousands of dollars in interest.

Entrepreneurs put money into various investments which give a greater return than directly servicing their loans. Their investments are important to them; Tim brought in a picture of his term investment and Mike brought in the agreement for sale and purchase of his real estate. 
You can use debt as a money making scheme, I did and it was a good option for me as I made a lot of money from doing so-Mike (Entrepreneur).

Both Entrepreneurs acknowledge that a credit card should only be used only as an interest free payment tool which helps avoid bank fees. They both see the potential risk of using credit cards; however, they use their credit cards in such a way that they avoid accruing interest.

I would not like to get into paying minimum balances, the credit card is used purely as a payment tool to avoid bank fees all while collecting my reward points—Mike (Entrepreneur).

As long as you are using your credit card as a tool, and not paying interest, then it is a smart financial option-Tim (Entrepreneur).

Both Entrepreneurs felt that people have to be sensible with their money and protect themselves. Mike even brought in a picture of condoms, which was his metaphor for protection-financial protection.

\section{The "Expedient Payees"}

Expedient Payees dramatically increased their regular payments so that they could repay their student loans very quickly - in less than four years. This group was willing to live frugally so that they could pay off their loan faster. Although Expedient Payees were adverse to purchasing items on credit, they will use credit cards as a payment tool to avoid bank transaction fees; however, they avoid accruing interest by paying the total credit card balance by its due date.

\section{Expedient Payees: Profile Of The Participants}

Nigel: 24 years old, Licensed Aircraft Maintenance Engineer, working full time. Nigel fully repaid his \$25,000 student loan within 6 months of graduating. Nigel is earning a six figure salary.

David: 28 years old, Bachelor of Commerce (Management), full time Data Processing Analyst, in the workforce for 5 years. David repaid his $\$ 24,000$ student loan within 3.5 years of graduation.

Joanna: 25 years old, Bachelor of Commerce (Marketing), full time Business Banking Manager, in the workforce for 4 years. Joanna fully repaid her $\$ 25,000$ student loan within 3 years of graduation.

Kevin: 21 years old, Bachelor of Commerce (Marketing), full-time Marketing Coordinator, in the workforce for nine months. In nine months Kevin has downsized his student loan from $\$ 18,000$ to $\$ 3,100$. Kevin plans to have his loan repaid in full within the following three months.

All of the Expedient Payees noted the importance of being wise with their money to enable them to pay back their student loan. Expedient Payees acknowledge how they had to become financially savvy and make sacrifices to relieve themselves of their student debt.

To pay back your student loan, you have to realise that you do not have an unlimited amount of funds and you have to become savvy with it. You can't sometimes do all the things you want to do and you have to be aware of what you have got and where you are going to spend it. Really paying back your student loan is the best form of savings-David (Expedient).

You have to be wise with the money you earn, and I think it is wise to pay back your loan as fast as you can by making as many payments as you can-Nigel (Expedient).

future.

The three Expedient Payees who had paid off their loans all talked about investments and their financial 
Now that I am free from student debt, I can look at buying a house as an investment type thing. Buying houses and making money on them interests me and hopefully with this money, it will enable me to look toward my future and enable me to retire early-Nigel (Expedient).

They also felt that since they have worked so hard to gain their education, get a well paying job, and pay back their student debt, they are well justified in rewarding themselves with various luxury goods such as cars, vacations, and the latest modern conveniences.

This not only symbolizes freedom once you have paid back your student loan, but the ability to reward yourself for sticking through college and applying yourself to pay back the student loan. If you have paid back this debt, your purchasing power has suddenly increased and you can look at things like cars and they are not a dream anymore-David (Expedient).

The three Expedient Payees who had paid off their loans also mentioned 'freedom'. Once the loan was paid off there was a freedom which enabled them to do the things that they wanted to do. They liked their new debtfree lives and tended to be averse to accruing additional debt as they want to maintain financial freedom and flexibility.

I am liberated without it. You know that you are not going to be seeing $\mathrm{x}$ amount of dollars coming out of your bank account. You have not got anything hanging over you, and you are not shackled by the debt. You know what you are now earning is yours to do with as you please-David (Expedient).

All these pictures denote freedom more than anything else. Before your whole world was encompassed by debt, and now it is like a whole new world with no financial burden which I plan to keep this way-Joanna (Expedient).

\section{DISCUSSION}

There were a number of themes consistently mentioned in the interviews. Almost all of the participants said that their student loans were always hanging over their heads and that it restricted what they could do. Although most of them knew what it would take to pay back the loan, it was difficult. Many of the participants also likened paying off the loan to an incredibly challenging event—climbing a mountain, cycling uphill—and there was a tremendous amount of pain associated with paying off the loan. Ultimately, everyone wanted financial freedomfreedom from debt, freedom to do what they pleased with the money they earned.

Three of the groups-Expedient Payees, Entrepreneurs, Traditionalists-seemed to understand the financial system and were willing to work within it to access the money necessary to fund their college education. Expedient Payees found student loans to be a necessary evil. They don't like debt, wanted to eliminate it as quickly as possible, and made significant sacrifices to do so. Traditionalists hold similar views but are not as extreme in their attitudes. For Traditionalists, debt is unpleasant and they want to minimize it, but they are more likely to methodically pay off their loans over what they deem to be a reasonable period of time - usually between five and seven years. Entrepreneurs are different in that they have very positive attitudes toward debt and are willing to incur large amounts of debt if they think they can benefit financially from investments derived from this money.

In comparison to these three groups, the Life Indebted are not dealing with debt in a way that is beneficial to them. They seem to be unaware how much extra they are paying by treating their student loan repayment as a life-long tax. They are trapped in a world of debt and don't know how to get out of it. The Life Indebted are a troublesome group, a group that needs help.

One form of help that is becoming more commonplace is 'debt counseling' (Elliehausen, Lundquist \& Staten, 2007). Debt counseling occurs after debt has become a problem and involves guiding clients to move beyond practical skills, like checkbook balancing and budgeting, to explore the emotional and spiritual traits that subconsciously affect their spending habits (Bridgforth, 1996). In her work, Bridgforth (1996) talks about one case 
in which a client revealed that many impulse purchases were actually efforts to make the client feel better about voids caused by unmet emotional needs.

Another approach that is gaining traction is related to education. Some of the major banks have begun early intervention programs that educate post-secondary students about budgeting, debt, and money management. The industry and government are taking a view that if they are going to lend money, particularly to students, then they must teach these students how to manage that debt (Schachter, 1997). Whether it is education from the lender or a debt counselor, there is one thing that most people agree upon-it is important for borrowers to pay back their debts. If they don't, there will inevitably be problems.

One of these problems is bankruptcy. As we know, there are an increasing number of people trying to escape their debt repayment obligations by making themselves bankrupt (Burd, 1998). In 1995-1996, a total of 7,850 people with student loans outstanding declared themselves bankrupt, a number that is twice the figure for 1990-1991 (Schachter, 1997). Sandra Ferguson, Vice-President of Student Product Management at CIBC Finance, notes that "students have to learn to understand that what they borrow is not a grant; it is a loan and the students have obligations to repay ... That applies to all loans, whether they come from government, your grandmother, or a financial institution" (Schachter, 1997).

With the increasing number of people declaring bankruptcy, it is important that we have a system in place that equips people with the information necessary to operate in our financial system in a way that is positive. We also need to ensure that people who get themselves into financial trouble can work their way out of the situation. People like Mike, who appears to be moving from Life Indebted to a Traditionalist, give us promise. However, we need to have a better understanding of when and why this type of transformation occurs, and it will take a considerable amount of research — both qualitative and quantitative - to come to a reasonable level of understanding.

Education can provide a stepping stone to economic independence, employment, and quality of life, and in the end, we want smart consumers who are well equipped to deal with our financial system, understand how the credit system works, and can use it to their advantage. This idea is nicely summed up by one of the participants.

You have worked so hard all the time ... You have gotten up at 7:00 and pulled your old clothes on, biked to school in the freezing cold, turned up at that 8 am lecture that is only half full, all while thinking 'why the hell is this worth it?', but in the end it has paid off-Joanna (Expedient Payee and debt free).

\section{REFERENCES}

1. Birdwhistell, R. L. (1970). Kinesics and Context: Essays on Body Motion Communication, Philadelphia, PA: University of Pennsylvania Press.

2. $\quad$ Bridgforth, G. (1996). Downsize your debt, Essence, 27(5), 91-92.

3. Burd, S. (1998). Debate flares over how bankruptcy law should apply to student borrowers, The Chronicle of Higher Education, 44(37), 38.

4. Chien, Y. and Devaney, S. (2001). The effects of credit attitude and socioeconomic factors on credit card and installment debt, Journal of Consumer Affairs, 35(1), 162-179.

5. Christen, M. and Morgan, R. (2005). Keeping up with the joneses: analyzing the effect of income inequality on consumer borrowing, Quantitative Marketing and Economics, 3, 145-173.

6. $\quad$ Clark, W. (1998). Paying off student loans, Canadian Social Trends, 51, 24-28.

7. Davies, E. and Lea, S. (1995). Student attitudes to student debt, Journal of Economic Psychology, 16(4), 663-679.

8. Duesenberry, J. (1949). Income, Saving and the Theory of Consumer Behavior, Cambridge: Harvard University Press.

9. Elliehausen, G., Lundquist, E., and Staten, M. (2007). The impact of credit counseling on subsequent borrower behavior, Journal of Consumer Affairs, 41(1), 1-28.

10. Hirschman, E. (1991). Secular morality and the dark side of consumer behavior, Advances in Consumer Research, 18, 1-4.

11. Knapp, M. (1980). Essentials of Nonverbal Communication, New York: Holt, Rinehart, and Winston. 
12. Lea, S., Webley, P., and Levine, R. (1993). The economic psychology of consumer debt, Journal of Economic Psychology, 14, 85-119.

13. Lea, S., Webley, P., and Walker, C. (1995). Psychological factors in consumer debt: Money management, economic socialization, and credit use, Journal of Economic Psychology, 16, 681-701.

14. Livingstone, S., and Lunt, P. (1992). Predicting personal debt and debt repayment: Psychology, social and economic determinants, Journal of Economic Psychology, 13, 111-134.

15. Lunt, P. and Livingston, S. (1991). Psychological, social and economic determinants of saving: comparing recurrent and total savings, Journal of Economic Psychology, 14(1), 621-641.

16. Ministry of Education (2004). Student Loan Scheme Annual Report, Wellington: New Zealand Government.

17. Modigliani, F. (1986). Life cycle, individual thrift, and the wealth of nations, American Economic Review, 76, 297-313.

18. O'Loughlin, D., and Szmigin, I. (2006). 'I'll always be in debt': Irish and UK student behaviour in a credit led environment, Journal of Consumer Marketing, 23(6), 335-343.

19. Park, S. (1993). The determinants of consumer instalment credit, Federal Reserve Bank of St. Louis, 75(6), 23-38.

20. Parker, G. (1988). Credit, in R. Walker and G. Parker (eds.), Money Matter: Income, Wealth and Financial Welfare, London: Sage.

21. Schachter, H. (1997). Course 101: managing debt, Canadian Banker, 104(2), 23-27.

22. Scott, R. (2007). Credit card use and abuse: a veblenian analysis, Journal of Economic Issues, 41(2), 567574.

23. Seiter, E. (1988). 'Semiotics and television,' In Channels of Discourse: Television and Contemporary Criticism, Robert C. Allen, ed. Chapel Hill, NC: The University of North Carolina Press.

24. Thums, S., Newman, B., and Xiao, J. (2008). Credit card debt reduction and developmental stages of the lifespan, Journal of Personal Finance, 6 (2/3), 86-107.

25. Watson, J. (2003). The relationship of materialism to spending tendencies, saving, and debt, Journal of Economic Psychology, 24, 723-739.

26. Weiser, J. (1988). 'See what I mean? Photography as nonverbal communication in cross-cultural psychology,' In F. Poyatos (Ed.), Cross-Cultural Perspectives in Nonverbal Communication, Hogrefe.

27. Williams, C. (2004). Financialaid.com expert offers five personal finance tips for the millions of college students who graduate with a degree and a debt, Business Wire, (May 18, 2004), 1.

28. Zaltman, G. and Coulter. R. (1995). Seeing the voice of the customer: Metaphor based advertising research, Journal of the Marketing Research Society, July/August, 35-51. 
NOTES 